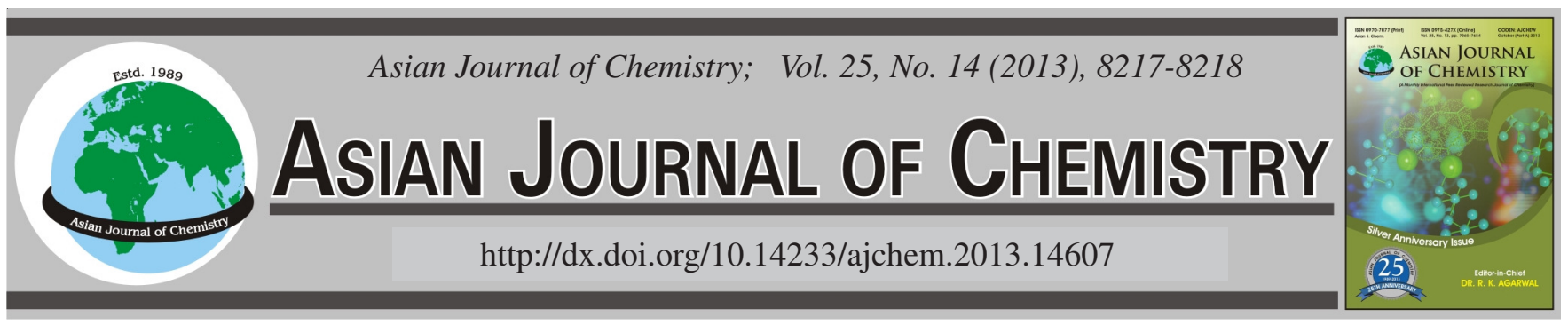

NOTE

\title{
Synthesis and Crystal Structure of Phosphorus Vanadium Heteropoly Acid Potassium Compound: $\left(\mathrm{K}_{12} \mathrm{P}_{4} \mathrm{~V}_{72} \mathrm{O}_{172}\right) \cdot 24 \mathrm{Cl} \cdot 24(\mathrm{OH}) \cdot 14.4 \mathrm{H}_{2} \mathrm{O}$
}

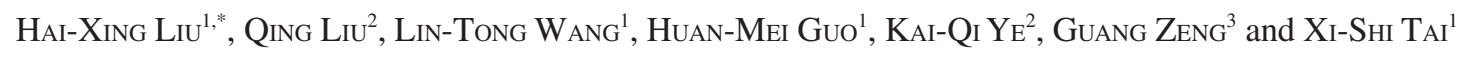

${ }^{1}$ Chemistry and Chemical and Environmental Engineering College, Weifang University, Weifang 261061, P.R. China

${ }^{2}$ College of Chemistry, State Key Laboratory of Supramolecular Structure and Materials, Jilin University, Changchun 130012, P.R. China

${ }^{3}$ State Key Laboratory of Inorganic Synthesis and Preparative Chemistry, College of Chemistry, Jilin University, Changchun 130012, P.R. China

*Corresponding author: E-mail: haixingliu@ tom.com

Key Words: Heteropoly acid, Structure analysis.

Polyoxometalates, as early transition-metal oxide clusters, bear many properties that make them attractive for applications in catalysis, separation, imaging, materials science and medicine $^{1}$. It should be noted that polyoxometalate, known as their wide applications in before-mentioned fields, is an outstanding class of inorganic components to build the interesting hybrid materials via two kinds of interactions, i.e. coordinate covalent bonds and weaker intermolecular forces. Furthermore, the construction of new polyoxometalate-based hybrid supramolecular frameworks with versatile organic ligands or metal complex moieties constitutes an emerging area, by means of weaker intermolecular forces such as hydrogen bond and $\pi-\pi$ stacking $^{2}$. It is well known that the Anderson-type polyoxoanions exhibit attractive planar structures. In addition, each Mo (or V) atom has two terminal oxygen atoms with high reactivity ${ }^{3,4}$, which may facilitate the construction of novel hybrid compounds. Recently, some new polyoxometalates complex have been reported $^{5-7}$.

All commercially obtained reagent-grade chemicals were used without further purication. A mixture of $\mathrm{CdCO}_{3}(0.1$ mmol, $0.017 \mathrm{~g}), \mathrm{NH}_{4} \mathrm{VO}_{3}(0.1 \mathrm{mmol}, 0.012 \mathrm{~g}), \mathrm{KCl}(0.1 \mathrm{mmol}$, $0.008 \mathrm{~g}), \mathrm{Na}_{2} \mathrm{HPO}_{4}(0.1 \mathrm{mmol}, 0.036 \mathrm{~g}), \mathrm{KOH}(0.2 \mathrm{mmol}$, $0.012 \mathrm{~g})$ and 1,2,3-benzotriazole $(0.1 \mathrm{mmol}, 0.012 \mathrm{~g})$ were added into $20 \mathrm{~mL}$ water with $40 \%$ (v/v) ethanol and heated for $12 \mathrm{~h}$ at $414 \mathrm{~K}$. The solution was obtained by filtration after cooling the reaction to room temperature. Brown block single crystals suitable for X-ray measu-rements were obtained after a few weeks. 1,2,3,-Benzotriazole does not take part in the reaction.

The molecular structure of the complex is shown in Fig. 1. Packing diagram of three-dimensional structure of the complex is shown in Fig. 2.

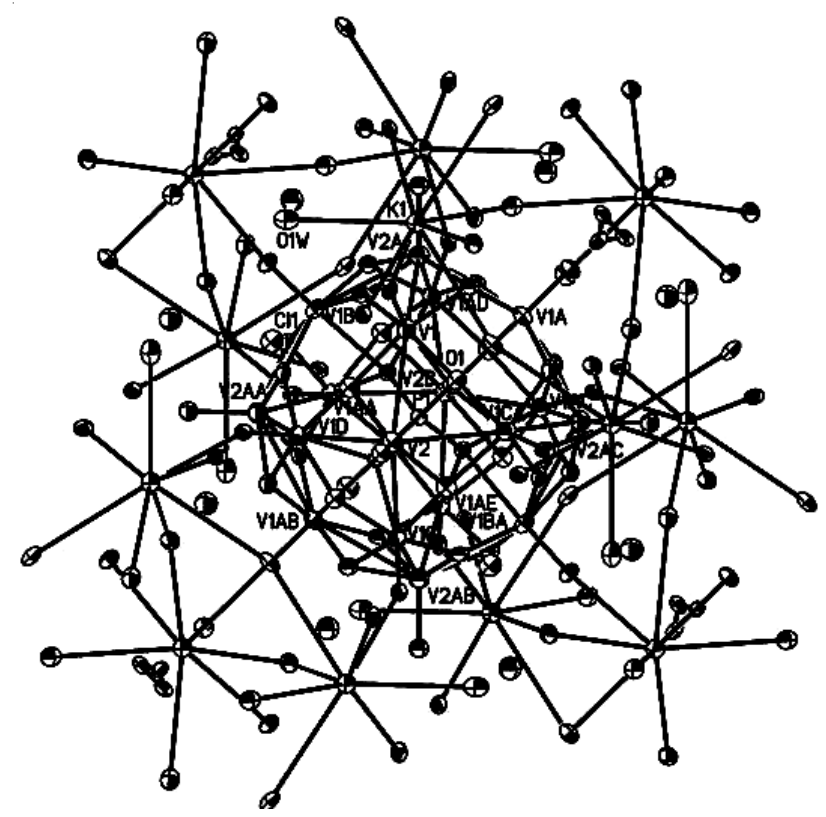

Fig. 1. Molecular structure of the title complex 


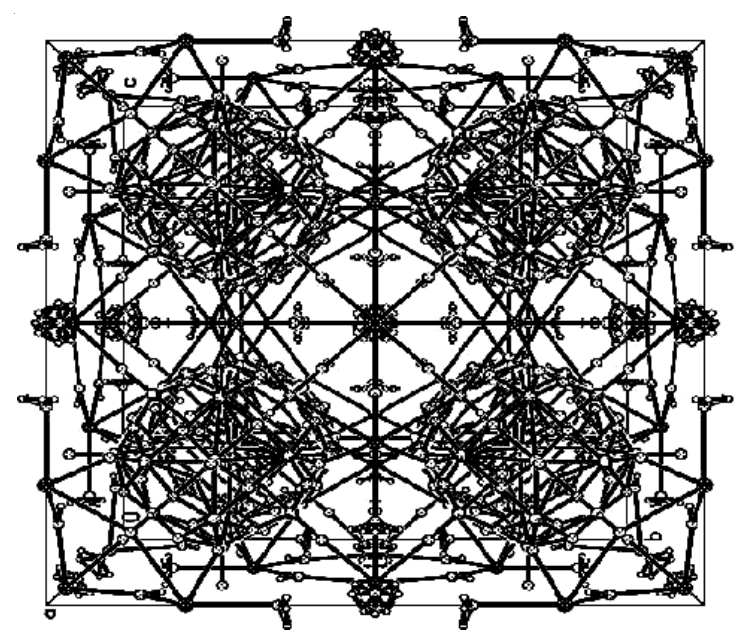

Fig. 2. Packing diagram of three-dimensional structure of the complex

The crystal data and structure refinement is shown in Table-1. The title crystal structure is built up P-V cluster, $\mathrm{Cl}$ anion, $\mathrm{K}$ cation and water molecules. A tetrahedral configuration is formed by a $\mathrm{P} 1$ atom and four $\mathrm{O} 1$ atoms. The $\mathrm{O} 1$ atom connectes three $\mathrm{V} 1$ atoms. The $\mathrm{V} 1$ atom is coordinated by six $\mathrm{O}$ atoms $(\mathrm{O} 1$, two $\mathrm{O} 2$, two $\mathrm{O} 3, \mathrm{O} 4)$. The $\mathrm{V} 2$ atom is coordinated by five $\mathrm{O}$ atoms (two $\mathrm{O} 2$, two $\mathrm{O} 3$, O5). There are three $\mu_{2}-\mathrm{O}$ atoms and a terminal $\mathrm{O} 1 \mathrm{w}$ atom. The $\mu_{2}-\mathrm{O} 4$ atom bridges $\mathrm{V} 1$ and $\mathrm{K} 1$ atom, while $\mu_{2}-\mathrm{O} 5$ atom bridges two V2 atoms, while $\mu_{2}-\mathrm{O} 6$ atom bridges two $\mathrm{K} 1$ atoms. The coplanar is formed of the atoms $(\mathrm{K} 1, \mathrm{O} 5, \mathrm{O} 6, \mathrm{O} 1 \mathrm{w})$. The coplanar is formed of the atoms $(\mathrm{P} 1, \mathrm{~V} 1, \mathrm{O} 1, \mathrm{O} 2, \mathrm{O} 4)$. The $\mathrm{d}(\mathrm{P}-\mathrm{O})$ is $1.544 \AA$. The $\mathrm{d}(\mathrm{V}-\mathrm{O})$ are in the range of $1.568-2.370 \AA$. The $\mathrm{d}(\mathrm{K}-\mathrm{O})$ are in the range of 2.842-3.356 $\AA$. Selected bond lengths and bond angles are shown in Table- 2 .

\begin{tabular}{|c|c|c|}
\hline \multicolumn{3}{|c|}{$\begin{array}{c}\text { TABLE-1 } \\
\text { CRYSTAL DATA AND STRUCTURE REFINEMENT } \\
\text { FOR THE TITLE COMPLEX }\end{array}$} \\
\hline Empirical formula & \multicolumn{2}{|c|}{$\mathrm{Cl}_{24} \mathrm{H}_{52.80} \mathrm{~K}_{12} \mathrm{O}_{210.40} \mathrm{P}_{4} \mathrm{~V}_{72}$} \\
\hline Formula weight & \multicolumn{2}{|c|}{8531.18} \\
\hline Temperature & \multicolumn{2}{|l|}{ 291(2) K } \\
\hline Wavelength & \multicolumn{2}{|l|}{$0.71073 \AA$} \\
\hline Crystal system, space group & \multicolumn{2}{|l|}{ Cubic, Fm-3m } \\
\hline \multirow[t]{3}{*}{ Unit cell dimensions } & $a=21.866(2) \AA$ & $\alpha=90^{\circ}$ \\
\hline & $\mathrm{b}=21.866(2) \AA$ & $\beta=90^{\circ}$ \\
\hline & $c=21.866(2) \AA$ & $\gamma=90^{\circ}$ \\
\hline Volume & $10454.6 \AA^{3}$ & \\
\hline Z, Calculated density & $2,2.710 \mathrm{Mg} / \mathrm{m}^{3}$ & \\
\hline Absorption coefficient & $3.745 \mathrm{~mm}^{-1}$ & \\
\hline $\mathrm{F}(000)$ & 8176 & \\
\hline Crystal size & $0.32 \times 0.29 \times 0.2$ & $\mathrm{~mm}$ \\
\hline Theta range for data collection & 2.64 to $26.92^{\circ}$. & \\
\hline Limiting indices & $\begin{array}{l}-26<=\mathrm{h}<=20,- \\
<=1<=26\end{array}$ & $<=\mathrm{k}<=25,-26$ \\
\hline Reflections collected/unique & 13453/574 [R(int & $=0.0584]$ \\
\hline Completeness to theta $=25.93$ & $100 \%$ & \\
\hline Absorption correction & Semi-empirical fr & m equivalents \\
\hline Max and min transmission & 0.5213 and 0.380 & \\
\hline Refinement method & Full-matrix least- & juares on $\mathrm{F}^{2}$ \\
\hline Data/restraints/parameters & $574 / 0 / 53$ & \\
\hline Goodness-of-fit on $\mathrm{F}^{2}$ & 1.093 & \\
\hline Final $R$ indices $[I>2 \sigma(I)]$ & $\mathrm{R} 1=0.0363, \mathrm{wR}$ & $=0.1191$ \\
\hline $\mathrm{R}$ indices (all data) & $\mathrm{R} 1=0.0479, \mathrm{wR}$ & $=0.1338$ \\
\hline Largest diff. peak and hole & 0.981 and -0.907 & \\
\hline
\end{tabular}

\begin{tabular}{|c|c|}
\hline \multicolumn{2}{|c|}{$\begin{array}{c}\text { TABLE-2 } \\
\left.\text { SELECT BOND LENGTHS [̊] AND ANGLES [ }{ }^{\circ}\right] \\
\text { FOR THE TITLE COMPLEX }\end{array}$} \\
\hline K1-O4 & $2.842(4)$ \\
\hline K1-O1W & $3.074(9)$ \\
\hline K1-O6 & $3.356(4)$ \\
\hline O1-P1 & $1.544(5)$ \\
\hline O1-V1 & $2.370(3)$ \\
\hline $\mathrm{O} 2-\mathrm{V} 2$ & $2.084(4)$ \\
\hline $\mathrm{O} 3-\mathrm{V} 2$ & $1.801(4)$ \\
\hline O3-V1 & $1.913(3)$ \\
\hline O4-V1 & $1.568(4)$ \\
\hline O5-V2 & $1.6480(15)$ \\
\hline O4-K1-O4 & $83.67(4)$ \\
\hline O4-K1-O6 & $137.78(4)$ \\
\hline O1W-K1-O6 & $122.79(9)$ \\
\hline O6-K1-O6 & 72.95(9) \\
\hline $\mathrm{O} 1 \mathrm{~W}-\mathrm{K} 1-\mathrm{O} 2 \mathrm{~W}$ & $175.1(4)$ \\
\hline P1-O1-V1 & $125.51(9)$ \\
\hline V1-O1-V1 & $89.65(13)$ \\
\hline $\mathrm{V} 1-\mathrm{O} 2-\mathrm{V} 2$ & $90.01(13)$ \\
\hline V2-O3-V1 & $98.67(12)$ \\
\hline V1-O4-K1 & $152.29(16)$ \\
\hline
\end{tabular}

It is striking that the structure of the title compound exhibits extensive hydrogen-bonding interactions

\section{ACKNOWLEDGEMENTS}

This study were supported by the Natural Science Foundation of Shandong Province (No. ZR2010BL025), State Key Laboratory of Inorganic Synthesis and Preparative Chemistry (Jilin University)(No. 2011-13), MOE Key Laboratory of Analytical Chemistry for Life Science (Nanjing University) (No. KLACLS1002) and the National Science Foundation of China (No. 21171132) and Open Project of State Key Laboratory of Supramolecular Structure and Materials (No. sklssm201323) (Jilin University).

\section{REFERENCES}

1. A. Müller, R. Sessoli, E. Krickemeyer, H. Bögge, J. Meyer, D. Gatteschi, L. Pardi, J. Westphal, K. Hovemeier, R. Rohlfing, J. Döring, F. Hellweg, C. Beugholt and M. Schmidtmann, Inorg. Chem., 36, 5239 (1997).

2. A. Dolbecq, P. Mialane, L. Lisnard, J. Marrot and F. Secheresse, Chem. Eur. J., 9, 2914 (2003).

3. D. Drewes, E.M. Limanski and B. Krebs, J. Chem. Soc. Dalton. Trans, 21, 2087 (2004).

4. H.X. Liu, F.F. Jian and J. Wang, J. Chem. Crystallogr., 40, 306 (2010).

5. H.-X. Liu, Z. Kristallogr. NCS, 226, 441 (2011).

6. H.X. Liu, J. Wang, Y.F. Li and F.F. Jian, J. Chem. Crystallogr., 41, 1254 (2011).

7. H.-X. Liu, Z. Kristallogr. NCS, 225, 243 (2010). 